\title{
SPATIAL PATTERNS AND FACTORS INFLUENCING THE MORTALITY OF SNAKES ON THE NATIONAL HIGHWAY-7 ALONG PENCH TIGER RESERVE, MADHYA PRADESH, INDIA
}

\author{
A.Pragatheesh ${ }^{1} \&$ Asha Rajvanshi ${ }^{1 *}$ \\ ${ }^{1}$ Wildlife Institute of India, Chandrabani, Dehradun, Uttarakhand, India. \\ E-mail: pragatheesh@gmail.com, ar@wii.gov.in
}

\begin{abstract}
Road induced habitat reduction and animal mortality pose the greatest challenge of conserving wildlife species in protected areas with extensive road networks. This study was conducted in a $9 \mathrm{~km}$ stretch of National Highway-7 passing through Pench Tiger Reserve in central India with an objective to assess impacts on wildlife species and their habitats. Considering that snakes are a vital part of food webs of every ecosystem and are more susceptible to vehicular causalities, we present the ecological impacts of the highway on snakes in this Tiger Reserve. We surveyed this highway section for a total of 430 road cruising days spread equally across three seasons and over two years from August 2008 to July 2010. We collected data on different variables influencing use of road side habitat, the road surface and the factors influencing mortality of snakes. We recorded a total of 490 snake road kills (approx.1.13 snakes/10km/day) during the study. We recorded the highest mortality (50\%) of snakes during monsoon. Barred wolf snake had the highest mortality (22\%) followed by Common cat snake (11\%) and Striped keel back (8\%). We identified fatality hotspots in different sections of the highway using Kernel Density Method. The linear regression model showed that the road kills were positively related to high elevation and negatively related to proximity of the agriculture fields, animal crossings and water sources.
\end{abstract}

Keywords: Protected area; road; ecological impacts; habitat fragmentation; road kill.

\section{RESUMO}

PADRÕES ESPACIAIS E FATORES QUE INFLUENCIAM A MORTALIDADE DE SERPENTES NA NATIONAL HAIGHWAY 7, AO LONGO DA RESERVA DE TIGRES DE PENCH, MADHYA

PRADESH, INDIA. A redução do habitat e a mortalidade dos animais provocada pelas estradas representam o maior desafio para a conservação das espécies selvagens em áreas protegidas com vasta rede rodoviária. Este estudo foi realizado em um trecho de $9 \mathrm{~km}$ da National Highway 7, ao longo da Reserva Pench Tiger, na Índia central, com o objetivo de avaliar os impactos sobre as espécies silvestres e seus habitats. Considerando que as serpentes são uma parte vital das cadeias alimentares de todo ecossistema e que são mais susceptíveis a acidentes com veículos, apresentamos os impactos ecológicos da estrada sobre as serpentes nessa Reserva de Tigres. Investigamos a seção da rodovia por 430 dias de amostragem distribuídos igualmente ao longo de três estações e durante dois anos, de Agosto de 2008 a Julho de 2010. Coletamos dados referentes a diferentes variáveis que influenciam o uso do habitat ao lado da estrada, o pavimento da estrada e os fatores que afetam a mortalidade das serpentes. Registramos um total de 490 serpentes mortas na estrada $(1,13$ serpente/10 km/ dia) durante o estudo. Registramos a mais alta mortalidade das serpentes (50\%) durante a monção. Lycodon striatus teve a maior mortalidade (22\%), seguida por Boiga trigonata (11\%) e Amphiesma stolatum (8\%). Identificamos os hotspots de mortalidade nas diferentes seções da rodovia utilizando o Método Kernel de estimativa de Densidade. As mortes na estradas foram positivamente relacionadas à altitude e negativamente relacionada à proximidade com as lavouras, passagens de animais e fontes de água.

Palavras-chave: Áreas protegidas; estrada; impactos ecológicos; fragmentação de habitat; atropelamento. 


\section{RESUMEN}

PATRONES ESPACIALES Y FACTORES QUE INFLUENCIAN LA MORTALIDAD DE SERPIENTES EN LA CARRETERA NACIONAL 7 A LO LARGO DE LA RESERVA DE TIGRES PENCH, MADHYA PRADESH, INDIA. La reducción de hábitat y mortalidad de animales debido a las carreteras representan el mayor desafío para la conservación de la vida silvestre en áreas protegidas con redes viales extensas. Este estudio fue realizado en un trecho de $9 \mathrm{~km}$ de la Carretera Nacional 7, que pasa a través de la Reserva de Tigres Pench en India central, con el objetivo de evaluar su impacto en especies de fauna y sus hábitats. Considerando que las serpientes son parte vital de las cadenas tróficas de todo ecosistema y son susceptibles a los accidentes con carros, presentamos los impactos ecológicos de esta carretera sobre las serpientes en la Reserva. Monitoramos esta carretera durante un total de 430 días distribuidos equitativamente entre tres estaciones y durante dos años, de Agosto de 2008 a Julio de 2010. Obtuvimos datos sobre diferentes variables que afectan el uso del hábitat al lado de la carretera, la superficie de la carretera y los factores que influyen en la mortalidad de serpientes. Registramos un total de 490 muertes de serpientes (ca. 1,13 serpientes $/ 10 \mathrm{~km} /$ día) durante el día. La mayor mortalidad (50\%) fue registrada en época de monzones. La serpiente lobo del norte (Lycodon striatus) tuvo la mayor mortalidad (22\%) seguida de la serpiente gato común (Boiga trigonata) (11\%) y la keelback rayada (Amphiesma stolatum) (8\%). Identificamos hotspots de mortalidad en diferentes secciones de la carretera usando métodos de densidad por núcleos. El modelo de regresión linear mostró que las muertes en carretera están relacionadas positivamente a elevaciones altas y negativamente con la proximidad de campos agrícolas, puntos de cruce para fauna y fuentes de agua.

Palabras clave: Área protegida; carretera; impactos ecológicos fragmentación de hábitat; muertes en carretera.

\section{INTRODUCTION}

India, with more than 3.31 million $\mathrm{km}$ existing road length, has the world's third largest road network (CIA 2013). Approximately 26,000km of road length traversing through wilderness areas are routed through as many as 30 tiger reserves spread across the country. The National Highway Authority of India proposes to further expand this network by adding new road links and also by widening existing roads to four lane roadway.

Roads represent one of the most widespread forms of modification of the natural landscape associated with expansion in transportation infrastructure that is often justified for facilitating linkages, enhancing mobility and improving accessibility. Several independent studies and comprehensive reviews of ecological impacts specific to roads have singled out roads as the largest factor posing the greatest threats to biodiversity (Treweek et al. 1993, Forman \& Alexander 1998, Smith 2003, Spellerberg 2002, Trombulak \& Frissell 2002, Seiler \& Seiler 2004, Eigenbrod et al. 2008, Fahrig \& Rytwinski 2009, Clevenger \& Sawaya 2010, Beckmann et al. 2010).

These studies have demonstrated that roads increase fragmentation of habitats and populations; lead to isolation and obstruction of animal movements; result in road induced mortality of animals and extinction of rare and endemic species (Oxley et al. 1974, Mader 1987, Mech 1989, Ashley \& Robinson 1996, Richardson et al. 1997, Forman \& Alexander 1998, Jackson 1999, Lode 2000, Trocmé et al. 2002, Goosem 2007).

Road related mortality has been widely documented on different taxa. For example, butterflies (Mckenna et al. 2001); amphibians (van Gelder 1973, Hels \& Buchwald 2001); snakes (Rosen \& Lowe 1994, Andrews \& Gibbons 2005, Row et al. 2006), birds (Reijnen et al. 1995, Erritzoe et al. 2003, Sundar 2004, Benitez-Lopez et al. 2010, Bujoczek et al. 2011) and mammals (Oxley et al. 1974, Vieira 1996, Clevenger et al. 2003, Roedenbeck \& Voser 2008).

As snakes play an important ecological role both as predators and prey in the different ecosystems, they command high significance for conservation. Snakes represent an ideal target group for studying direct and indirect impacts of roads (Andrews \& Gibbons 2005) not only because road related mortality has been documented for over half a century (for example, Krivda 1993, Smith \& Dodd 2003, Gibson \& Merkle 2004, Row et al. 2006), but also because of the breadth of ecological niches represented among snake species (Ernst \& Ernst 2003) and their greater vulnerability to roads. The tendency of snakes to thermo regulate 
on road surfaces, their relatively slow locomotion, life history characteristics, low reproductive rates and seasonal variability in habitat use are factors that increase their vulnerability to roads (Rosen \& Lowe 1994, Rudolph et al. 1999, Jochimsen et al. 2004).

Although knowledge about the ecological impacts of road on snakes is rapidly accumulating from many parts of the world (Bernardino \& Dalrymple 1992, Rosen \& Lowe, 1994, Gibson \& Merkle 2004, Shine et al. 2004, Jochimsen 2005, Andrews et al. 2007, Freeman \& Bruce 2007, McDonald 2012), studies on impacts of roads on snakes are scarce in India. Also, most of the studies are limited to a few disparate records of road induced mortality of snakes in tropical evergreen and moist deciduous forests (Gokula 1997, Vijayakumar et al. 2001, Kannan 2007, Das et al 2007, Baskaran \& Boominathan 2010, Seshadri \& Ganesh 2011, Bhupathy et al. 2011). No studies on road related impacts on snakes have been conducted in the forested landscapes in central India. The present study was undertaken to fill the void of such studies in the tropical dry deciduous forests of central India. The objective of our study was to (i) estimate the road related mortality of snakes in the $9 \mathrm{~km}$ section of National Highway (NH) -7 passing through Pench Tiger Reserve, (ii) define the spatial distribution of road kills (iii) evaluate the factors influencing the mortality of snakes and (iv) propose mitigation options to prevent and reduce the road induced mortality of snakes for ensuring the long term conservation of the snakes in this landscape.

\section{STUDY AREA}

NH-7 runs across the country from North to South cuts through an important forest corridor which connects the two tiger reserves - Kanha and Pench Tiger Reserves in the central Indian landscape. Our study was conducted on a $9 \mathrm{~km}$ stretch of National Highway (NH-7) between Kurai village ( $21^{\circ} 49^{\prime} \mathrm{N}$, $\left.79^{\circ} 30^{\prime} \mathrm{E}\right)$ and Gandatola village $\left(21^{\circ} 53^{\prime} \mathrm{N}, 79^{\circ} 32^{\prime}\right.$ E) aligned along the Pench Mowgli Sanctuary, falling within the Eastern boundary of the Pench Tiger Reserve (Figure1). This NH-7 is a two lane, $7 \mathrm{~m}$ wide roadway without a defined median strip for incoming and outgoing traffic lanes. NH-7 runs North-South
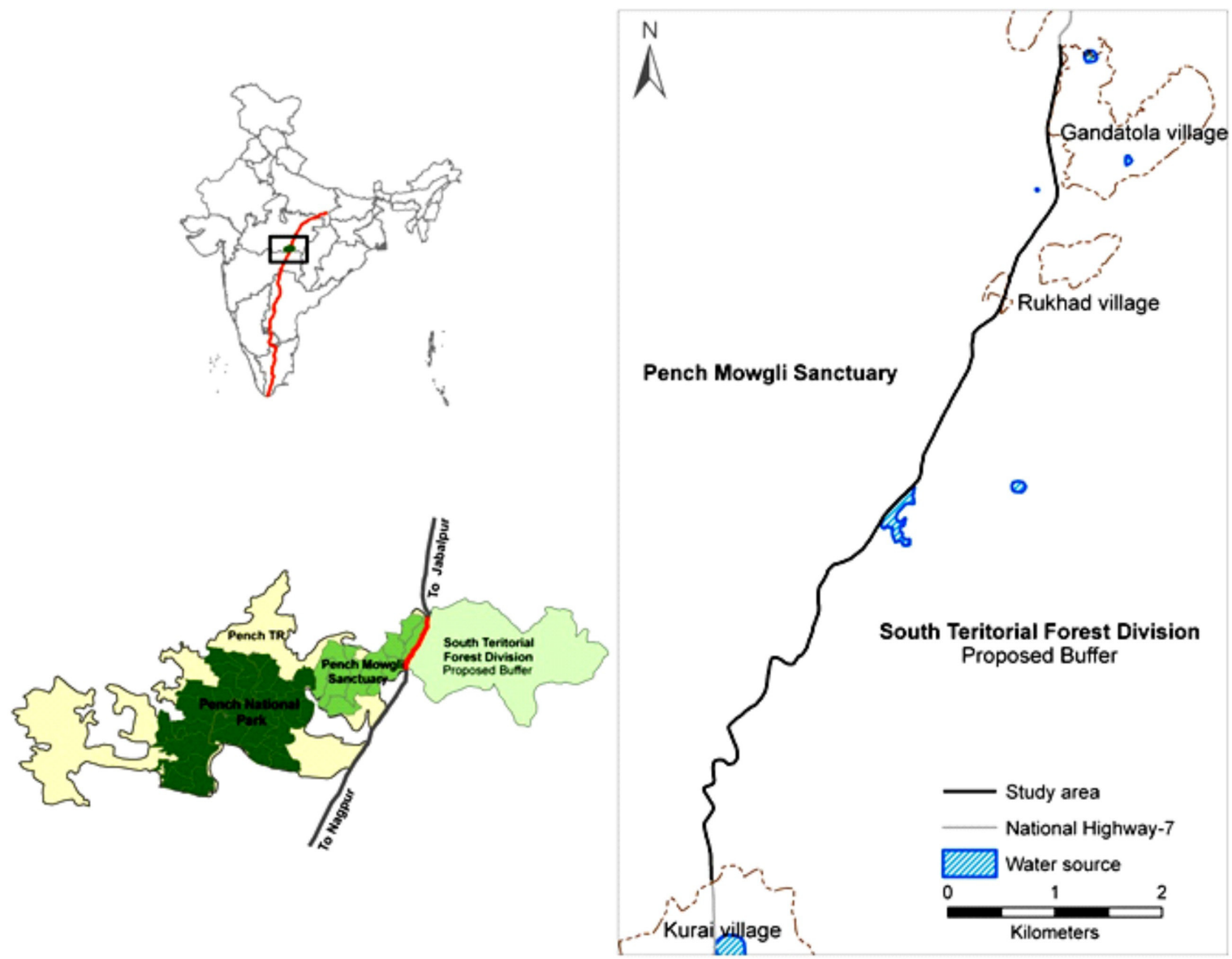

Figure 1. Study area and the Pench Tiger Reserve. 
and has two topographically distinct sections: $4 \mathrm{~km}$ of the northern portion of the road aligned in the flatter terrain and $5 \mathrm{~km}$ of the southern road section aligned through a hilly terrain. The study area represents a forested tract buffering the Pench Tiger Reserve which is bifurcated by NH-7. The altitude of the road section ranges from approximately $400 \mathrm{~m}$ to $600 \mathrm{~m}$ above sea level. In the entire $9 \mathrm{~km}$ section of the road, the area is characterized by Tectona grandis (teak) dominated forest which is interspersed with miscellaneous species such as Acacia spp. Anogeissus latifolia, Mallotus philippensis, Madhuca indica, Terminalia spp. and species of bamboo on gentle and steep slopes and nine seasonal streams intersecting the road. The annual rainfall averages $1400 \mathrm{~mm}$ with the SouthWest monsoon accounting for most of the rainfall in the region. The average daily maximum temperature was a minimum of $0^{\circ} \mathrm{C}$ in winter and maximum of $45^{\circ} \mathrm{C}$ in summer.

\section{METHODS}

\section{ROAD-KILL DATA COLLECTION}

We adopted road cruising and collecting method that has been widely used to determine species negatively impacted by roads (Ashley \& Robinson 1996, Clevenger et al. 2003, Langen et al. 2007). The entire $9 \mathrm{~km}$ stretch of highway was surveyed for a total of 430 road cruising days spread equally across three seasons: monsoon/July to October $(n=147)$, winter/November to February $(\mathrm{n}=143)$ and summer/ March to June ( $\mathrm{n}=140$ ) between August 2008 to July 2010. On all cruising days, the vehicular survey was conducted in the morning $(0530-0630 \mathrm{hrs})$ and in the evening $(1730-1830 \mathrm{hrs})$ at a speed of $10-20 \mathrm{~km} /$ hr. Observations about snakes kills were recorded by two observers. Whenever the snake kills were encountered on the road, the vehicle was stopped to enable the team to identity the species (Whitaker \& Captain 2004). Additionally information on the state of the road kills, geo-coordinates of the road kills (using Garmin 72 GPS) and roadside habitat features were recorded. After recording the information, the dead snakes were removed from the road to avoid repeat count during subsequent surveys. The 430 days of vehicular survey resulted in a total effort of surveying $3870 \mathrm{~km}$. Information on average traffic volume per day and peak traffic was collected through continuous monitoring based on manual counts for three days per season in a two year period.

Data on average traffic volume on the road section passing along the Pench Tiger Reserve was generated based on continuous recording of the number of vehicles over a period of twenty four hours for three days per season. Total number of two wheelers, passenger cars, heavy vehicles, trucks and lorries moving. Data on traffic was collected on week and non week days and market days to capture any variations in traffic volume on different days.

\section{PREDICTION OF FATALITY HOTSPOTS}

Fatality hotspots were determined on the $9 \mathrm{~km}$ section of the road, using Kernel density estimation method (Gitman \& Levine 1970) which is one of the common methods for analyzing the point event distribution data (Silverman 1986, Bailey \& Gatrell 1995). This method generates a smooth surface map showing point data (kill location) on the basis of which the density of events (road kills per unit area) is determined to provide an estimate of kill concentration. This approach of identifying fatality hotspots provides a useful insight for planning mitigation strategies to avoid and reduce road kills in high mortality zones (Ramp et al. 2005, 2006, Gomes et al. 2009). The area of influence or a bandwidth chosen for this study was $200 \mathrm{~m}$. The kernel estimation for species fatalities was done using the Spatial Analyst toolbox of ArcGIS version-9 (ESRI 2004). Zero values were omitted to avoid confusion between zero density and no data.

\section{FACTORS INFLUENCING THE ROAD KILL}

The road area was also typified to assess the road features that may have influence on the frequency and abundance of snake mortality. The road was categorized into six categories following Clevenger et al. (2003): (i) road surface raised compared to surrounding landscape, (ii) no slope, iii) road surface buried relative to surrounding landscape, (iv) one side flat, one buried, (v) one side flat, one side raised and (vi) one side buried, one raised. 
We created land use land cover classified map using Landset 7 Thematic Mapper (30m resolution) acquired on November 2009 (Path: 144, Row: 52) and downloaded from the US Geological Survey archive Global Visualization Viewer (http://glovis. usgs.gov). The image was classified into five major cover types spanning across both the sides of the road as (1) Teak dominant, (2) Miscellaneous, (3) Scrub forest, (4) Agriculture and (5) Water sources. A 50m buffer was created around each road kill location that was treated as a point in the GIS domain. Information was extracted from classified image on habitat type.

On encountering a snake kills on the road, the distance from the snake kill to the closest vegetation cover on both sides of the road was recorded using a range finder. The nearest distance at which the kill could have been visible to a driver of the vehicle was assessed by measuring the nearest distance between the point of road and an unobstructed view of the approaching vehicle from either side of the highway. Spatial data (Table 1) on landscape related variables: distance of the kill from the agriculture, water sources, drainage and animal crossing structures was generated in GIS laboratory using the Euclidean distance method in Arc Info. Altitude (meter) and slope (degree) was derived from 30m resolution Digital Elevation Model (ASTER Global Digital Elevation Model).

A linear regression model was developed to relate the occurrence of road-kills to the landscape and road attributes. The $9 \mathrm{~km}$ road was divided into $100 \mathrm{~m}$ segments $(\mathrm{n}=90)$ and the road kill data was segregated for each of these segments. In each segment, number varied from 0 to 15 road kills. We chose 8 variables to describe site-specific attributes of each road-kill site (Table I). We used the SPSS statistical package (version 15.0, SPSS 2006) for all statistical analysis, Arc GIS 9 (ESRI 2004) and Microsoft Excel for all other analysis.

Table 1. Landscape and site variables and their description used in the analysis.

\begin{tabular}{|c|c|c|}
\hline Variable name & Description & Source \\
\hline Visibility (m) & $\begin{array}{l}\text { Farthest distance from which the driver can locate a } \\
\text { snake on the road }\end{array}$ & Field \\
\hline Distance to cover $(\mathrm{m})$ & $\begin{array}{l}\text { Distance of vegetation cover from the location of the } \\
\text { road kill }\end{array}$ & Field \\
\hline Distance to water (m) & $\begin{array}{l}\text { Distance of the road kill from the nearest water source } \\
\text { (lake) }\end{array}$ & Euclidean distance(Arc Info) \\
\hline $\begin{array}{l}\text { Distance to animal crossing } \\
\text { structure }(\mathrm{m})\end{array}$ & $\begin{array}{c}\text { Distance of the road kill from the nearest animal } \\
\text { crossing structure }\end{array}$ & Euclidean distance(Arc Info) \\
\hline Distance to drainage $(\mathrm{m})$ & Distance of the road kill to nearest seasonal drainage & Euclidean distance(Arc Info) \\
\hline Distance to agriculture (m) & Distance of the road kill to nearest human settlements & Euclidean distance(Arc Info) \\
\hline Altitude (m) & Mean ground altitude of the road (100m segments) & Digital elevation model \\
\hline Slope (Degree) & Mean ground slope of the road ( $100 \mathrm{~m}$ segment) & Digital elevation model \\
\hline
\end{tabular}

\section{RESULTS}

\section{TRAFFIC VOLUME}

From the data we collected (Figure 2) during the study, average traffic flow recorded on the $9 \mathrm{~km}$ road was $3035 \pm 274$ vehicle/day. The average traffic volume varied between summer (3269 vehicle/day), winter (2952 vehicle/day) and monsoon (2884 vehicle/ day). The highest average daily traffic was recorded on Sundays (3382 vehicle/day) during summer and minimum traffic was recorded on Tuesdays (2620 vehicle/day) during monsoon. Number of heavy vehicles (trucks) remained highest in the overall total 
traffic volume in all of the three seasons). The traffic flow during late night and early morning hours was recorded to be the lowest ( 80 vehicles/hr/day) in all seasons. The traffic peaked (180 vehicles/hr/day) during evening $(1600 \mathrm{hr}$ and $1700 \mathrm{hr})$ in all seasons. Road kills of snakes has a strong positive correlation with the number of vehicles plying on the road $(\mathrm{r}=$ $0.99, \mathrm{p}<0.001)$ in all seasons.

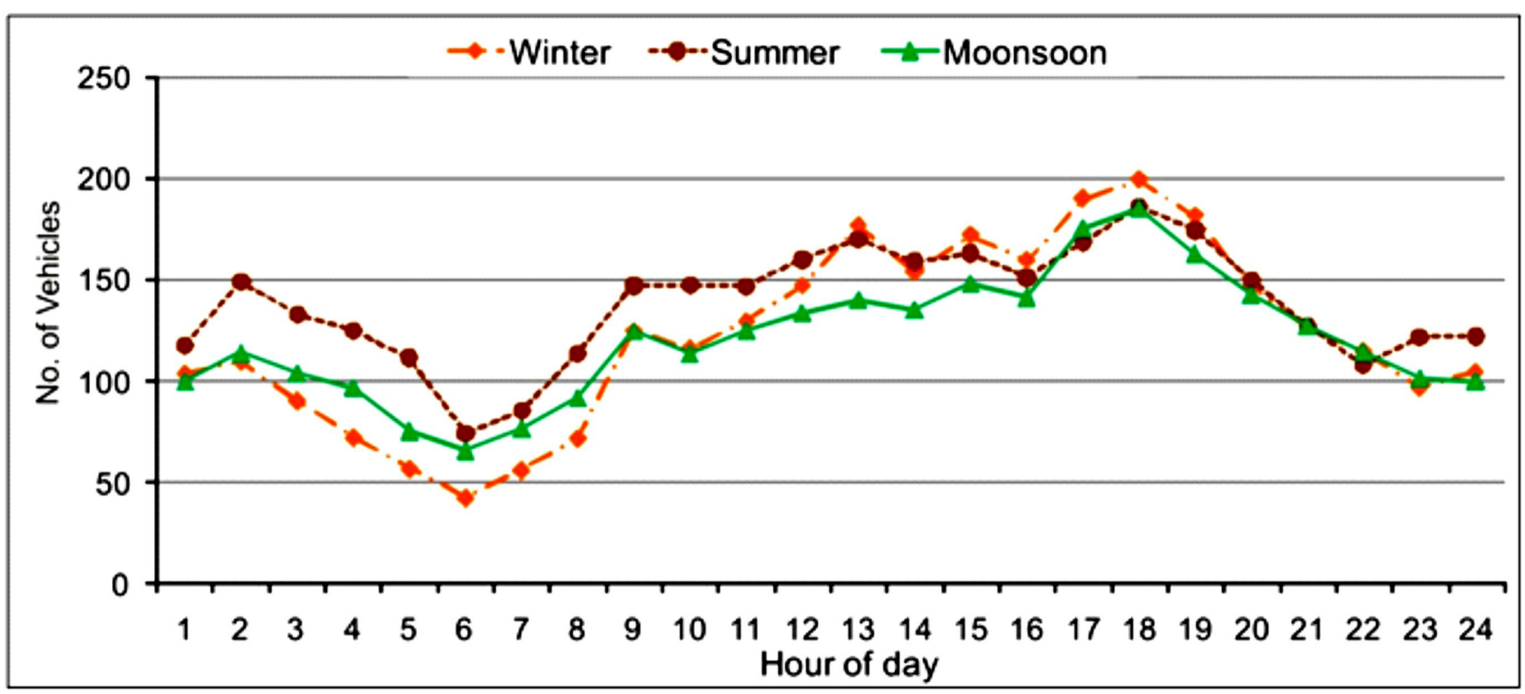

Figure 2. Average traffic volume on the National Highway - 7

\section{SPECIES COMPOSITION AND TEMPORAL PATTERN OF ROAD KILLS}

Based on 430 days of observations and $3870 \mathrm{~km}$ of effort between August 2008 to July 2010, 490 road kills of snakes were recorded (Table 2). These together represented 20 different species. Many of the species that have contributed to the road kills command high conservation importance. The Indian rock python is listed under Schedule I and 4 species (Checkered keelback, Indian rat snake Russell's viper and Spectacled cobra are listed under Schedule II list of Indian Wild Life Protection Act (WPA), 1972. The Indian python is also listed in Appendix -I of the CITES (2012).

The snakes were killed at the rate of 1.13 animal $/ 10 \mathrm{~km} /$ day. The number of snake kills varied seasonally. The highest mortality was recorded during monsoon (50\%), followed by $37 \%$ of snakes killed in summer and 13\% snakes killed in winter. Of the total count of 490 snakes kills recorded during the study, Barred wolf snake (Lycodon striatus) had the highest number of mortality $(n=99)$ representing $22 \%$ of the total snakes killed. This was followed by Common cat snake, Boiga trigonata $(\mathrm{n}=49$,) and Striped keelback, Amphiesma stolatum $(\mathrm{n}=38$,) representing $11 \%$ and $8 \%$ of the total road kill respectively.

Table 2. List of snake species killed on National Highway -7.

\begin{tabular}{|c|c|c|c|c|c|}
\hline Common name & Scientific name & Family & $\begin{array}{c}\text { Percentage } \\
\text { of taxa }\end{array}$ & WPA status* & CITES** \\
\hline Bamboo pit viper & Trimeresurus gramineus & Viperidae & 1 & Schedule IV & not listed \\
\hline Barred wolf snake & Lycodon striatus & Colubridae & 22 & Schedule IV & not listed \\
\hline Beaked worm snake & Grypotyphlops acutus & Typhlopidae & 3 & Schedule IV & not listed \\
\hline Checkered keelback & Xenochrophis piscator & Colubridae & 3 & Schedule II & Appendix III \\
\hline
\end{tabular}




\begin{tabular}{|c|c|c|c|c|c|}
\hline Common name & Scientific name & Family & $\begin{array}{l}\text { Percentage } \\
\text { of taxa }\end{array}$ & WPA status* & CITES** \\
\hline $\begin{array}{l}\text { Common bronzeback tree } \\
\text { snake }\end{array}$ & Dendrelaphis tristis & Colubridae & 3 & Schedule IV & not listed \\
\hline Common cat snake & Boiga trigonata & Colubridae & 11 & Schedule IV & not listed \\
\hline Common krait & Bungarus caeruleus & Elapidae & 3 & Schedule IV & not listed \\
\hline Common kukri snake & Oligodon arnesis & Colubridae & 2 & Schedule IV & not listed \\
\hline Common sand boa & Gongylophis conicus & Boidae & 2 & Schedule IV & Appendix II \\
\hline Common trinket snake & $\begin{array}{c}\text { Coelognathus helena } \\
\text { helena }\end{array}$ & Colubridae & 5 & Schedule IV & not listed \\
\hline Common wolf snake & Lycodon aulicus & Colubridae & 3 & Schedule IV & not listed \\
\hline Forstens cat snake & Boiga forsteni & Colubridae & 2 & Schedule IV & not listed \\
\hline Green keelback & $\begin{array}{l}\text { Macropisthodon } \\
\text { plumbicolor }\end{array}$ & Colubridae & 4 & Schedule IV & not listed \\
\hline Indian rat snake & Ptyas mucosa & Colubridae & 2 & Schedule II & Appendix II \\
\hline Indian rock python & $\begin{array}{l}\text { Python molurus } \\
\text { molurus }\end{array}$ & Pythonidae & 3 & Schedule I & Appendix I \\
\hline Russell's kukri snake & Oligodon taeniolatus & Colubridae & 2 & Schedule IV & not listed \\
\hline Russell's viper & Daboia russelii & Viperidae & 4 & Schedule II & Appendix III \\
\hline Saw scaled viper & Echis carinatus & Viperidae & 4 & Schedule IV & not listed \\
\hline Spectacled cobra & Naja naja & Elapidae & 1 & Schedule II & Appendix II \\
\hline Striped keelback & Amphiesma stolatum & Colubridae & 8 & Schedule IV & not listed \\
\hline Unidentified & - & - & 12 & - & - \\
\hline
\end{tabular}

*WPA-Wildlife Protection Act, 1972

**CITES- Convention on International Trade in Endangered Species of Wild Fauna and Flora

\section{PREDICTION OF FATALITY HOTSPOTS}

Mortality of snakes occurred almost on the entire length of the road which traversed through rich tracts of wildlife habitats and cut across dispersal corridors of many endangered species. The Kernel density estimates of snakes (Figure 3), reflects that the high abundance of fatalities of snake occur on the road section aligned through the flatter areas and in locations nearer to villages that have agriculture fields. In the hilly area, kills were mostly concentrated in the road bends.

\section{FACTORS INFLUENCING THE ROAD KILL}

In general, the movement of snakes is likely to be influenced by habitat type, terrain and land-use. In our study, we also attempted to associate snake kills with road topography that is differentiated into six categories (buried, buried-raised, flat, part buried, part raised and raised) for the purpose of this study. Percentage of snake kills recorded in the flat section of the road (Figure 4) is highest $(42 \%)$ when compared to $27 \%$ of road kills recorded in the hilly area where the road is partly buried and partly raised. 


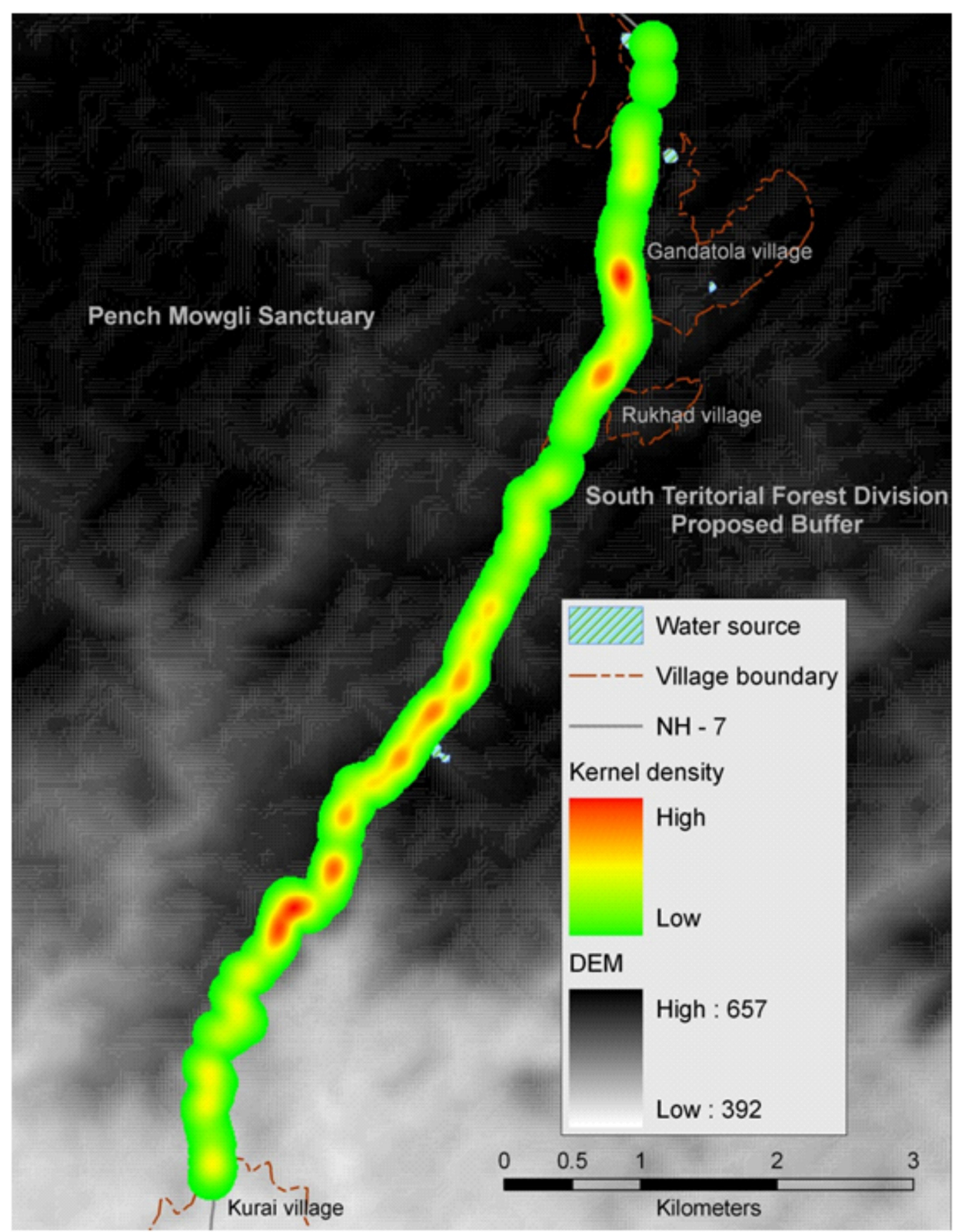

Figure 3. Kernel density estimation of snake fatalities.

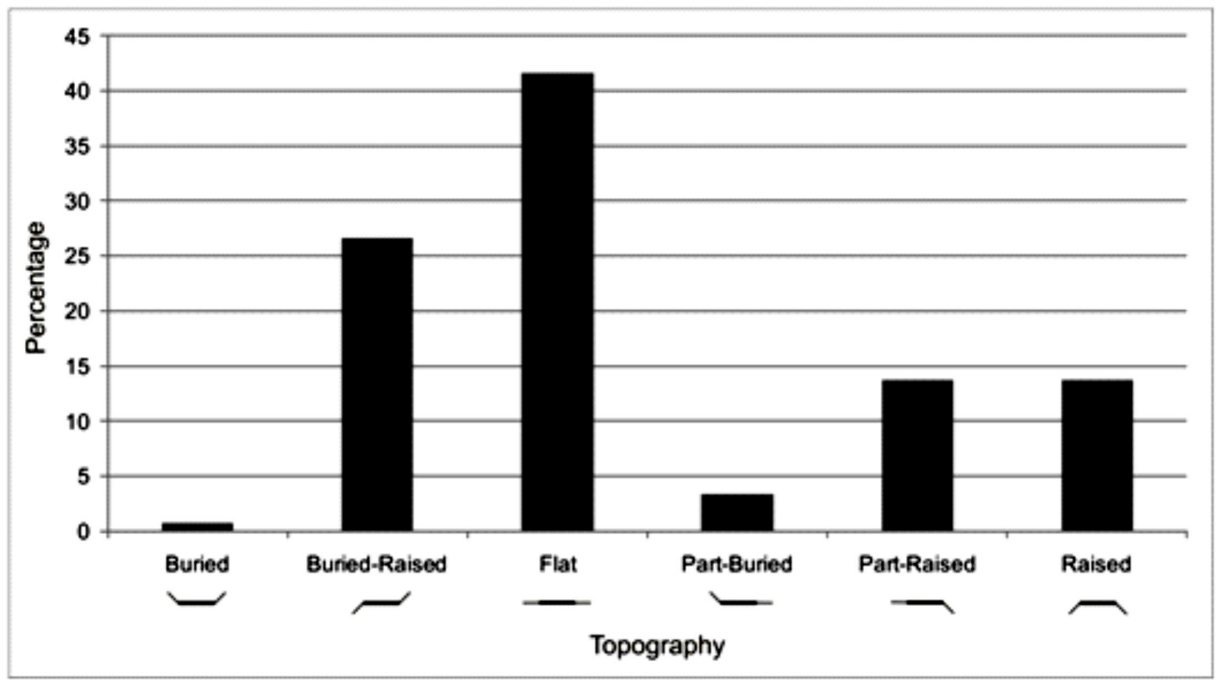

Figure 4. Percentage of snake kills in different topography. 
Our data shows that the highest percentage of snake mortality (43\%) occurred in road sections passing through Teak dominated forest (Figure 5). These forest tracts on either side of the road offer excellent habitat for varied species of animal ranging from large carnivores (for example, tiger, leopard and wild dog) and herbivores (for example, chital, sambar and nilgai) to smaller creeping animals (snakes) that frequently use the road as a conduit for movement across the two habitats. The results of our studies are similar to other studies that indicate that concentrations of road-killed animals generally occur where wooded areas or cover adjoins both sides of a road (Hodson 1962, Bellis \& Graves 1971, Bennett 1991, Clevenger et al. 2003). The lowest mortality $(6 \%)$ of snakes occurred in road sections passing through Scrub forest which is a fairly degraded habitat. As the large water body (Figure 1) forms the aquatic habitat just abutting the road in the hilly section, it is mostly avoided by snakes. This explains the low percentage of snake kills on the road segment near the water body.

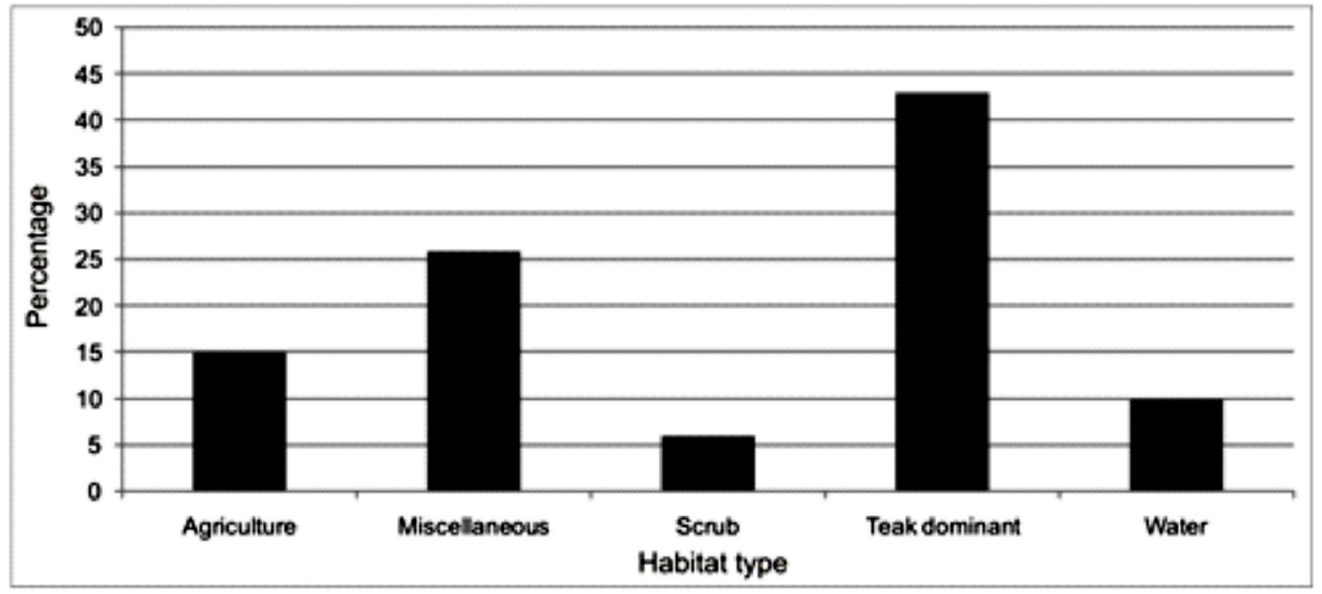

Figure 5. Mortality rate in different habitat type.

The linear regression $\left(\mathrm{R}^{2}=0.79\right)$ shows that the snake kill is positively correlated with elevation and negatively correlated with the distance to agricultures fields, water and the animal crossings. Other variables such as distance to vegetation cover, visibility distance, distance to drainage and slope did not influence the probability of the road kill (Table 3). Most of the flatter segment of the road where highest number of snake kills has been recorded is aligned through the elevated areas in the landscape.

Table 3. Linear regression of snake kills with the selected variables, $\beta$ - Regression coefficient, $S . E$ - standard error of the regression coefficient, $P$ - significance level

\begin{tabular}{lccc}
\hline Variables & $\boldsymbol{B}$ & $\boldsymbol{S} . \boldsymbol{E}$ & $\boldsymbol{P}$ \\
\hline Distance to cover & 0.035 & 0.045 & 0.556 \\
Distance to drainage & 0.021 & 0.002 & 0.730 \\
Distance to animal crossings & $\mathbf{- 0 . 1 2 7}$ & $\mathbf{0 . 0 0 1}$ & $\mathbf{0 . 0 9 8}$ \\
Distance to agriculture & $\mathbf{- 0 . 4 3 2}$ & $\mathbf{0 . 0 0 0}$ & $\mathbf{0 . 0 0 1}$ \\
Distance to water & $\mathbf{- 0 . 1 2 6}$ & $\mathbf{0 . 0 0 0}$ & $\mathbf{0 . 0 5 8}$ \\
Elevation & $\mathbf{0 . 7 8 0}$ & $\mathbf{0 . 0 0 3}$ & $\mathbf{0 . 0 0 1}$ \\
Slope & 0.071 & 0.044 & 0.295 \\
Visibility & -0.050 & 0.004 & 0.417 \\
\hline
\end{tabular}




\section{DISCUSSION}

A total of 490 snake kills representing 20 different species were recorded during the study. Of the nearly 270 species of snakes reported (Whitaker \& Captain 2004) from different parts of the country, approximately 40 species have been reported from the central Indian landscape (Chandra \& Gajbe 2005) and of these, 19 species have been reported from Pench Tiger Reserve, by Pasha et al. (2000). The present study supports the occurrence of as many as 20 species in this area. It is an already acknowledged fact that snake kills serve as a good indicators of the herpetofaunal species of the area (Hels \& Buchwald 2001) and the road cruising and collecting methods are valuable tools for studying snakes (Gibson et al. 2004, Mukherjee 2007). We suspect that there may be more species of snakes occurring in this area. Subsequent road cruising and collection efforts may thus be useful in the inventorying of snake species of this area.

The average mortality rate $(1.13$ animal $/ 10 \mathrm{~km} /$ day) of snakes varied seasonally. Coelho et al. (2008) also observed seasonal variation in the road kill pattern. This variability may be associated with changes in movement patterns of snakes during breeding and dispersal seasons. This variability could also be a reflection of spatial and temporal variations in environmental characteristics and availability of resources. The high mortality during monsoon can be explained by the fact that snakes are cold blooded animal and they tend to rest on road surfaces during cooler nights (Dodd et al.1989, Rosen \& Lowe 1994, Shine et al. 2004).

Road kills of snakes has a strong positive correlation with traffic on the road $(r=0.99, p<0.001)$. Szerlag \& McRobert (2006) also reported positive relationship between traffic volume and mortality of herpetofauna. Compared to other herpetofauna, snakes are at the highest risk of mortality as their movement is relatively slower on a smooth road as compared to other surfaces (Bonnet et al. 1999, Roe et al. 2006). Row et al. (2007) observed that some drivers deliberately run the vehicles over snakes because they dislike snakes. In the present study also, one of the authors observed the drivers attempting to kill the snakes moving on the road.

Nearly $72 \%$ of the snakes that get killed are nocturnal. Some species of snakes that actively forage during night time are relatively more vulnerable to the vehicles when compared to snakes that sit and wait for their prey and snakes which are active throughout the day. In the present study, high mortality of snakes could be explained because $52 \%$ of the snakes were nocturnal and actively feeding during night (Figure 6), $23 \%$ of the snakes sit and wait for the prey and are therefore less vulnerable to traffic. Of the total count of 490 snakes kills recorded during the study, Barred wolf snake and Common cat snakes which accounted for nearly $22 \%$ and $11 \%$ of road kills respectively are both nocturnal and active feeders (Whitaker \& Captain 2004).

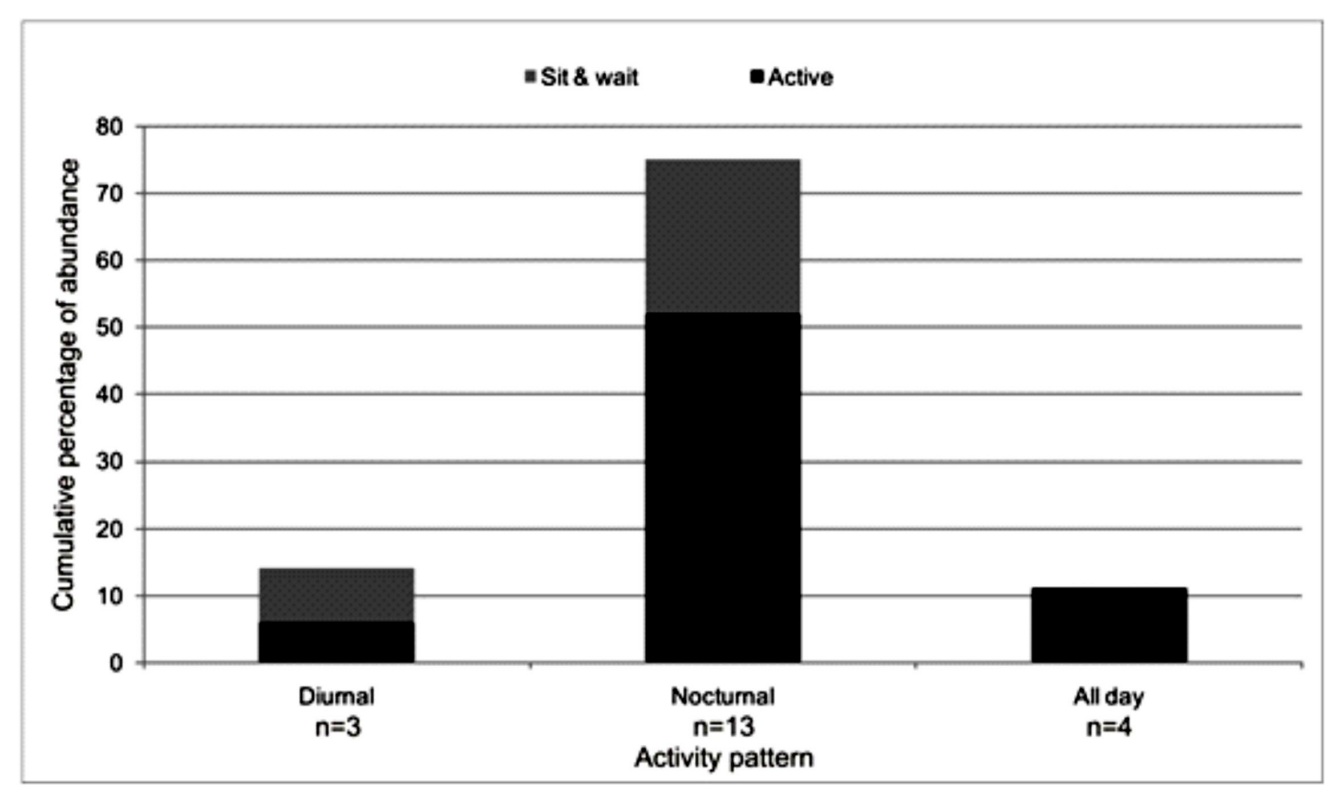

Figure 6. Activity pattern and foraging habit of the snake kills. 
Our study indicates that fatalities of snakes occur throughout the entire length of the road. This observation renders support to the fact that snakes continue to attempt to use habitat that has been dissected by the road which poses a major barrier for their movement. Similar conclusions that road act as barrier for snakes especially for smaller species were also drawn from studies by Andrews \& Gibbons (2005), Aresco (2005), Row et al. (2007), Shepard et al. (2008).

Although fatalities were recorded throughout the road, kills did not occur randomly along the entire 9 $\mathrm{km}$ length of the roads but were spatially clustered. Kernel density and linear regression analysis indicates higher snake mortalities near areas of anthropogenic influence including human settlements and agricultural fields in flat areas (Figure 3). Prey availability in the agricultural area tends to attract nocturnal snakes on the road during night that are more often killed by speeding vehicles in flat areas. Our findings support the observations of Puglisi et al. (1974), Clevenger et al. (2001), Joyce \& Mahoney (2001), Huijser et al. (2006) that wildlife-vehicle collisions do not occur randomly along roads but are spatially clustered.

Several factors including specific habitats, terrain and adjacent land-use types that influence wildlife movements also play an important role in determining locations of higher probability of road mortality compared to other locations (Forman \& Alexander 1998). We attempted to relate road kills with landscape and site variables within the road corridor (Table1). Higher moisture, lower temperature and presence of leaf litter that modify the micro habitat conditions in culverts and the prey availability in agricultural fields both improve the prospects of use of by active feeders. More kills therefore occurred at locations that were closer to drainage channels and near agricultural areas. Similarly, in sections of road that were closer to water bodies, more kills were recorded. This is perhaps because many of the snake species that get attracted to the prey species occurring near water sources attempt to cross the road and get killed in the process.

\section{IMPLICATIONS FOR CONSERVATION}

Road mortality plays a significant role in the decline of snake populations. This poses significant conservation challenges for species that are already endangered or species that are at risk on account of alteration of their habitat conditions. During our study, we recorded 12 kills of Indian rock python which is listed in schedule-I under the Wild Life (Protection) Act, 1972, Government of India. Of these, 9 individuals were juvenile. The road induced loss of dispersing juveniles and consequent isolation is likely to have impact upon the gene flow across the landscape. Ciesiolkiewicz et al. (2006) also recorded that juvenile snakes appear to be most susceptible to road mortality, especially during hatching and dispersal.

Common bronzeback tree snake, constituting 3\% $(n=14)$ of species killed by the vehicle during this study, is an arboreal species that is threatened by the reduction of canopy connectivity and by the road induced fragmentation of connectivity between the road side habitat. The threat to snake species may vary with differential mortality of animals that cross more slowly (eg. Russell's viper) than with snakes that immobilize, or freeze in response to a passing vehicle.

Drawing population estimates for the various species of snakes based on our records of snakes killed on road alone could be misleading as the relative kill rates by species may not correspond to their relative abundance locally. It is important to consider that low mortality percentages of some species of snakes (Green keelback, Beaked worm snakes and Russell's kukri snakes) could be a function of a smaller population of uncommon snakes (Whitaker $\&$ Captain 2004) found in the forested habitat outside protected areas.

\section{MITIGATION}

Habitat fragmentation of wildlife habitats by roads is globally recognised as one of the biggest threats to conservation of biodiversity (Andrews 1990, Seiler 2001, Bekker et al. 2003, Andrews \& Gibbons 2005, Shepard et al. 2008). This study serves as a useful template for assessing the nature and magnitude of vehicle induced mortality of snakes based on observations on a section of National Highway-7 aligned along an important protected area in central India. Understanding these impacts is critical for determining appropriate conservation strategy because of the importance of snakes as 
trophic components of terrestrial ecosystems (Rosen \& Lowe 1994). Mitigation approaches to address road induced mortality of snakes have been well discussed by many workers (Aresco 2005, Jochimsen et al. 2004, Trembath \& Fearn 2008, Coelho et al. 2008). These approaches have focused largely on improving the permeability of roads as passage for wildlife, managing traffic to reduce barrier effect of moving vehicles and managing wildlife areas to prevent snakes frequenting on roads.

In the present context, construction of speed breakers in fatality hotspots, and use of fences specifically engineered for snakes are some of the conventional approaches that can be effective in reducing road induced mortality. Most of these postconstruction mitigation measures would however serve only as second best option because they are not targeted to avoid the effects of roads in first place. Further, planning of retrofitting measures is often more costly. Developing ecologically sensitive approaches and innovative design that can be applied both at the planning stage and also subsequently as a retrofit would be most effective in controlling road kills. One such measure of constructing $1 \mathrm{~m}$ high wall with a lip on the high end along the road length through forest stretches is recommended by Dodd et al. (2004) for preventing snakes from getting on to the road. The feasibility and success of such measures will however depend on the characteristics of the road corridor.

The authors have likewise considered the options of proposing a mitigation measure to address the ecological requirement of thermoregulation that may be the primary factor influencing the number of individual snakes on roads or the time spent on the road surface during any foray to a road (Brattstrom 1965, Moore 1978, Sullivan 1981, Bernardino \& Dalrymple 1992, Ashley \& Robinson 1996). The authors recommend placing strips of individual surfaces that are attractive from a thermoregulatory perspective along the road in high mortality zones determined in this study (Figure 7). Such measures can be initially implemented on the experimental basis and once tested for their effectiveness, can be subsequently replicated in other road schemes. Results and practical guidance from this research should significantly reduce the mortality of Indian rock python and Russell's viper that command high conservation importance.

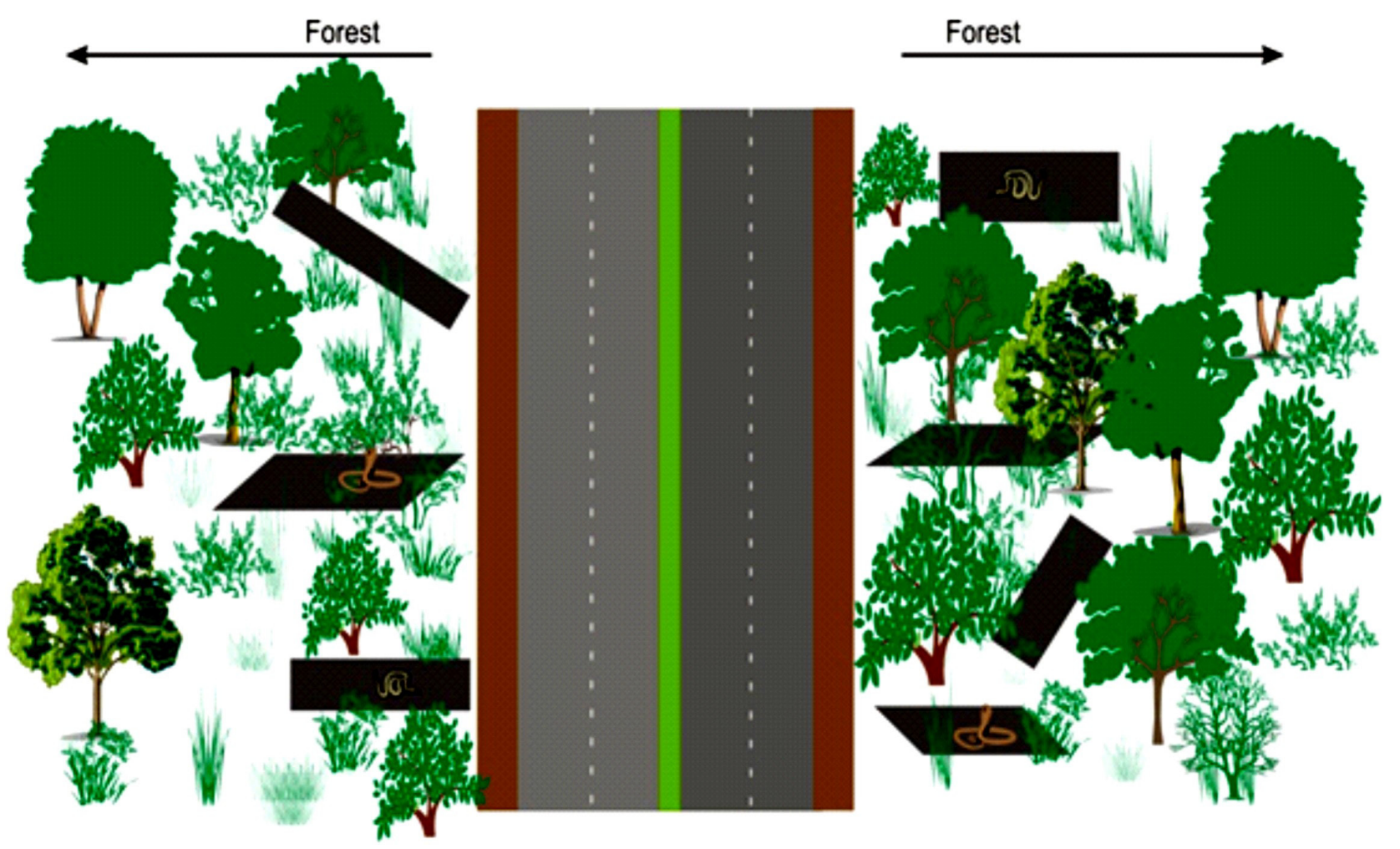

Figure 7. Creation of alternative sites for thermoregulation of snakes. 
ACKNOWLEDGEMENTS: We thankfully acknowledge Director and Dean, Wildlife Institute of India for their support and encouragement to undertake this study. We are grateful to the Chief Wildlife Warden, Madhya Pradesh Forest Department for permitting us to conduct field studies in the Pench Tiger Reserve. We greatly benefitted from interactions with colleagues Dr. K. Ramesh, Mr. Qamar Qureshi and Dr. KarthikeyanVasudevan from Wildlife Institute of India in the preparation of the manuscript.

\section{REFERENCES}

ANDREWS, A. 1990. Fragmentation of habitat by road and utility corridors: A review. Australian Zoologist, 26: 130-142.

ANDREWS, K.M. \& GIBBONS J.W. 2005. How do highways influence snake movement? Behavioral responses to roads and vehicles. Copeia, 772-782, http://dx.doi.org/10.1643/00458511(2005)005[0772:HDHISM]2.0.CO;2

ANDREWS, K.M.; GIBBONS, J.W. \& JOCHIMSEN, M. 2007. Ecological effects of roads on amphibians and reptiles: a literature review. Herpetological Conservation, 3.

ARESCO, M.J. 2005. Mitigation measures to reduce highway mortality of turtles and other herpetofauna at a North Florida Lake. Journal of Wildlife Management, 69: 540-551, http:// dx.doi.org/10.2193/0022-541X(2005)069[0549:MMTRHM]2.0. $\mathrm{CO} ; 2$

ASHLEY, E.P. \& ROBINSON, J.T. 1996. Road mortality of amphibians, reptiles and other wildlife on the Long Point Causeway, Lake Erie, Ontario. Canadian Field- Naturalist, 110: 403-412.

BAILEY, T.C. \& GATRELL, A.C. 1995. Interactive Spatial Data Analysis. Longman, New York. 413p.

BASKARAN, N. \& BOOMINATHAN, D. 2010. Road kill of animals by highway traffic in the tropical forests of Mudumalai Tiger Reserve, southern India. Journal of Threatened Taxa, 2: 753-759.

BECKMANN, J.P.; CLEVENGER, A.P.; HUIJSER, M.P. \& HILTY, J.A. (eds.). 2010. Safe passages: highways, wildlife and habitat connectivity. Island Press, Washington, D.C. 424p.

BEKKER, L.B.; CUPERUS, G.J.; DUFEK, R.; HICKS, F.G.; KELLER, H.V.; ROSELL, C.; SANGWINE, T.; WANDALL \& MAIRE, B.L. 2003. Wildlife and Traffic: A European Handbook for Identifying Conflicts and Designing Solution. Pp. 1-14. In: The XXIInd PIARC World Road Congress. Durban, South Africa. 1 CD-ROM.

BELLIS, E.D. \& GRAVES, H.B. 1971. Deer mortality on a Pennsylvania interstate highway. Journal of Wildlife Management, 35: 232-237, http://dx.doi.org/10.2307/3799596
BENITEZ-LOPEZ, A.; ALKEMADE, R. \& VERWEIJ, P.A. 2010. The impacts of roads and other infrastructure on mammal and bird populations: a meta-analysis. Biological Conservation, 143:1307-1316, http://dx.doi.org/10.1016/j.biocon.2010.02.009

BENNETT,A.F. 1991. Roads, roadsides and wildlife conservation: a review. Pp. 99-117. In: D.A. Saunders \& R.J. Hobbs (eds.). Nature Conservation 2: the Role of Corridors. Surrey Beatty \& Sons, Chipping Norton, Australia.

BERNARDINO, J. \& DALRYMPLE, G.H. 1992. Seasonal activity and road mortality of the snakes of the Pa-hay-okee wetlands of Everglades National Park, USA. Biological Conservation, 61: 71-75, http://dx.doi.org/10.1016/00063207(92)90928-G

BHUPATHY, S.; SRINIVAS, G.; SATHISH, N.; KARTHIK, T. \& MADHIVANAN, A. 2011. Herpetofaunal mortality due to vehicular traffic in the western ghats, India: A case study. Herpetotropicos, 5: 119-126.

BONNET, X.; NAULLEAU, G. \& SHINE, R. 1999. The dangers of leaving home: dispersal and mortality in snakes. Biological Conservation, 89: 39-50, http://dx.doi.org/10.1016/S00063207(98)00140-2

BRATTSTROM, B.H. 1965. Body temperatures of reptiles. American Midland Naturalist, 73: 376- 422, http://dx.doi. org/10.2307/2423461

BUJOCZEK, M.; CIACH, M. \& YOSEF, R. 2011. Road-kills affect avian population quality. Biological Conservation, 144: 1036-1039, http://dx.doi.org/10.1016/j.biocon.2010.12.022

Central Intelligence Agency. 2013. The World Factbook. https://www.cia.gov/library/publications/the-world-factbook/ rankorder/2085rank.html

CHANDRA, K. \& GAJBE, P.U. 2005. An inventory of Herpetofauna of Madhya Pradesh and Chhattisgarh. Zoos' Print Journal, 20: 1812-1819, http://dx.doi.org/10.11609/JoTT. ZPJ.1087.1812-9

CIESIOLKIEWICZ, J.; RLOWSKI, G. \& ELZANOWSKI, A. 2006. High juvenile mortality of grass snakes Natrix natrix (L.) on a suburban road. Polish Journal of Ecology, 54: 465-472.

CLEVENGER, A.P.; CHRUSZCZ, B. \& GUNSON, K.E. 2001. Highway mitigation fencing reduces wildlife vehicle collisions. Wildlife Society Bulletin, 29: 646-653.

CLEVENGER, A.P. \& SAWAYA, M.A. 2010. Piloting a noninvasive genetic sampling methods for evaluating populationlevel benefit of wildlife crossing structure. Ecology and Society, 15: 7 . 
CLEVENGER, A.P.; CHRUSZCZ, B \& GUNSON, K.E. 2003. Spatial patterns and factors influencing small vertebrate fauna road-kill aggregations. Biological Conservation, 109: 15-26, http://dx.doi.org/10.1016/S0006-3207(02)00127-1

COELHO, I.P.; KINDELAND, A. \& COELHO, A.V.P. 2008. Roadkills of vertebrate species on two highways through the Atlantic Forest Biosphere Reserve, southern Brazil. European Journal Wildlife Reserch, 54: 689-699, http://dx.doi.org/10.1007/ s10344-008-0197-4

CITES (CONVENTION ON INTERNATIONAL TRADE IN ENDANGERED SPECIES OF WILD FAUNA AND FLORA).

Reservations Entered by Parties. <www.cites.org>. (Acesso em 26/08/2012).

DAS, A.; AHMED, M.F.; LAHKAR, B.P. \& SHARMA, P. 2007. A preliminary report of reptilian mortality on road due to vehicular movement near Kaziranga National Park, Assam, India. Zoos' Print Journal, 22: 2742-2744.

DODD, C. K.; ENGE, K.M. \& STUART, J.N. 1989. Reptiles on highways in north-central Alabama, USA. Journal of Herpetology, 23: 197-200, http://dx.doi.org/10.2307/1564036

DODD, C.K.; BARICHIVICH, W.J. \& SMITH, L.L. 2004. Effectiveness of a barrier wall and culverts in reducing wildlife mortality on a heavily traveled highway in Florida. Biological Conservation, 118: 619-631, http://dx.doi.org/10.1016/j. biocon.2003.10.011

EIGENBROD, F.; HECNAR, S.J. \& FAHRIG, L. 2008. Accessible habitat: an improved measure of the effects of habitat loss and roads on wildlife populations. Landscape Ecology, 23: 159-168, http://dx.doi.org/10.1007/s10980-007-9174-7

ERNST, C.H. \& ERNST, E.M. 2003. Snakes of the United States and Canada. Smithsonian Press, Washington, D.C.

ERRITZOE, J.; MAZGAJSKI, T.D. \& REJT, L. 2003. Bird casualties on European roads-a review. Acta Ornithologica, 38: $77-93$.

ESRI. 2004. ArcGIS 9. Environmental System Research Institute, New York.

FAHRIG, L. \& RYTWINSKI, T. 2009. Effects of roads on animal abundance: an empirical review and synthesis. Ecology and Society, 14: 21 .

FORMAN, R.T.T. \& ALEXANDER, L.F. 1998. Roads and their major ecological effects. Annual Review of Ecology and Systematics, 29: 207-231, http://dx.doi.org/10.1146/annurev. ecolsys.29.1.207
FREEMAN, A. \& BRUCE, C. 2007. The things you find on the road: road-kill and incidental data as an indicator of habitat use in two species of tropical pythons. Pp. 152-165. In: R. Henderson \& R. Powell (eds.). Biology of the Boas and Pythons. Eagle Mountain Publishing, Eagle Mountain.

GIBSON, J.D. \& MERKLE, D.A. 2004. Road Mortality of Snakes in Central Virginia. Banisteria, 24: 8-14.

GITMAN, I. \& LEVINE, M.D. 1970. An algorithm for detecting unimodal fuzzy sets and its application as a clustering technique. IEEE Trans Computer, 19: 583-593, http://dx.doi.org/10.1109/ T-C.1970.222992

GOKULA, V. 1997. Impact of vehicular traffic on snakes in Mudumalai Wildlife Sanctuary. Cobra, 27: 26-30.

GOMES, L.; GRILO, C.; SILVA, C. \& MIRA, A. 2009. Identification methods and deterministic factors of owl road kill hotspot locations in Mediterranean landscapes. Ecological Research, 24: 355-370, http://dx.doi.org/10.1007/s11284-0080515-Z

GOOSEM, M. 2007. Fragmentation impacts caused by roads through rainforests. Current Science, 93: 1587-1595.

HELS, T. \& BUCHWALD, E. 2001. The effect of road kills on amphibian populations. Biological Conservation, 99: 331-340, http://dx.doi.org/10.1016/S0006-3207(00)00215-9

HODSON, N.L. 1962. Some notes on the causes of bird road casualties. Bird Study, 9: 168-173, http://dx.doi. org/10.1080/00063656209476024

HUIJSER, M.P.; GUNSON, K.E. \& ABRAMS, C. 2006. Wildlife-vehicle collisions and Habitat Connectivity Along Montana Highway 83 in the Seeley-Swan Valley, Montana: A Reconnaissance. Western Transportation Institute Report No. FHWA/MT-05-009/8177, Montana State University, Bozeman, MT. 160p.

JACKSON, S. 1999. Overview of transportation-related wildlife problems. Pp 1-4. In: G.L. Evink et al. (eds.). Proceedings of the Third International Conference on Wildlife Ecology and Transportation (ICOWET). FL-ER- 73-99. Florida Dept. of Transportation, Tallahassee, Florida. 330p.

JOCHIMSEN, D.; PETERSON C.R.; ANDREWS, K.M. \& GIBBONS, J.W. 2004. A Literature Review of the Effects on Roads the Measures used to Mitigate those Effects. Final Report to Idaho Fish and Game Department and the USDA Forest Service. $78 p$.

JOCHIMSEN, D.M. 2005. Factors influencing the road mortality of snakes on the upper Snake River Plain, Idaho. Pp. 351-365. In: 
C.L. Irwin, P. Garret \& K.P. McDermott (eds.). Wildlife Impacts and Conservation Solutions. North Carolina State University, North Carolina.

JOYCE, T.L. \& MAHONEY, S.P. 2001. Spatial and temporal distributions of moose-vehicle collisions in Newfoundland. Wildlife Society Bulletin, 29: 281-291.

KANNAN, P. 2007. Mortality of reptiles due to vehicular traffic in Mudumalai Wildlife Sanctuary, Western Ghats, Tamil Nadu, India. Cobra, 1:1-3.

KRIVDA, W. 1993. Road kills of migrating garter snakes at the Pas, Manitoba. Blue Jay, 51:197-198.

LANGEN, T.A.; MACHNIAK, A.; CROWE, E.K.; MANGAN, C.; MARKER, D.F.; LIDDLE, N. \& RODEN, B. 2007. Methodologies for surveying Herpetofauna mortality on rural highways. Journal of Wildlife Management, 71: 1361-1368, http://dx.doi.org/10.2193/2006-385

LODE, T. 2000. Effect of a motorway on mortality and isolation of wildlife populations. Ambio, 29: 163-166.

MADER, H.J. 1987. Animal Habitat Isolation by Roads and Agricultural Fields. Biological Conservation, 29: 81-96, http:// dx.doi.org/10.1016/0006-3207(84)90015-6

McDONALD, P.J. 2012. Snakes on roads: An arid Australian perspective. Journal of Arid Environments, 1-4.

MCKENNA, D.; MCKENNA, K.; MALCOM, S. \& BERENBAUM, M. 2001. Mortality of Lepidoptera along roadways in central Illinois. Journal of the Lepidopterists Society, 55: 63-68.

MECH, L.D. 1989. Wolf population survival in an area of high road density. American Midland Naturalist, 121: 387-389, http:// dx.doi.org/10.2307/2426043

MOORE, R.G. 1978. Seasonal and daily activity patterns and thermoregulation in the southwestern speckled rattlesnake (Crotalus mitchelli pyrrhus) and the Colorado desert sidewinder (Crotalus cerastes laterorepens). Copeia, 439-442, http://dx.doi. org/10.2307/1443608

MUKHERJEE, D. 2007. Resource utilization patterns of reptiles in the tropical dry mixed deciduous forest of Anaikatty Hills, Western Ghats, India. PhD Thesis. Bharathiar University, Coimbatore, India. 150p.

OXLEY, D.J.; FENTON, M.B. \& CARMODY, G.R. 1974. The effects of roads on populations of small mammals. Journal of Applied Ecology, 11: 51-59, http://dx.doi.org/10.2307/2402004
PASHA, M.K.S.; AREENDRAN, G.; SANKAR, K. \& QURESHI, Q. 2000. A preliminary checklist of snakes of Pench Tiger Reserve, Madhya Pradesh, Cobra, 40: 5-8.

PUGLISI, M.J.; LINDZEY, J.S. \& BELLIS, E.D. 1974. Factors Associated with Highway Mortality of White-tailed Deer. Journal of Wildlife Management, 38: 799-807, http://dx.doi. org/10.2307/3800048

RAMP, D.; CALDWELL, J.; KATHRYN, A.E.; WARTON, D. \& CROFT, D.B. 2005. Modelling of wildlife fatality hotspots along the Snowy Moutain Highway in New South Wales, Australia. Biological Conservation, 126: 474-490, http://dx.doi. org/10.1016/j.biocon.2005.07.001

RAMP, D.; WILSON,V.K. \& CROFT, D.B. 2006. Assessing the impact of roads in peri-urban reserves: Road-based fatalities and road usage by wildlife in the Royal National Park, New South Wales, Australia. Biological conservation, 129: 348-359, http:// dx.doi.org/10.1016/j.biocon.2005.11.002

REIJNEN, R.; FOPPEN, R.; TERBRAAK, C. \& THISSEN, J. 1995. The effects of car traffic on breeding bird populations in woodland Reduction of density in relation to the proximity of main roads. Journal of Applied Ecology, 32: 187-202, http:// dx.doi.org/10.2307/2404428

RICHARDSON, J.H.; SHORE, R.F. \& TREWEEK, J.R. 1997. Are major roads a barrier to small mammals? Journal of Zoology London, 243: 840-846, http://dx.doi. org/10.1111/j.1469-7998.1997.tb01982.x

ROE, J.H.; GIBSON, J. \& KINGSBURY, B.A. 2006. Beyond the wetland border: estimating the impact of roads on two species of water snakes. Biological Conservation, 130: 161-168, http:// dx.doi.org/10.1016/j.biocon.2005.12.010

ROEDENBECK, I.A. \& VOSER, P. 2008. Effects of roads on spatial distribution, abundance and mortality of brown hare (Lepus europaeus) in Switzerland. European Journal of Wildlife Research, 54: 425 -437, http://dx.doi.org/10.1007/s10344-0070166-3

ROSEN, P.C. \& LOWE, C.H. 1994. Highway mortality of snakes in the Sonoran Desert of Southern Arizona. Biological Conservation, 68: 143-148, http://dx.doi.org/10.1016/00063207(94)90345-X

ROW, J.R.; BLOUIN-DEMERS, G. \& WEATHERHEAD, P.J. 2007. Demographic effects of road mortality in black ratsnakes (Elaphe obsoleta). Biological Conservation, 137: 117-124, http:// dx.doi.org/10.1016/j.biocon.2007.01.020 
RUDOLPH， D.C.; BURGDORF， S.; CONNER， R.N. \& SCHAEFER, R. 1999. Preliminary evaluation of the impact of roads and associated vehicular traffic on snake populations in eastern Texas. Pp 129-136. In: G.L. Evink, P. Garrett, D. Zeigler \& J. Berry (eds.). Proceedings of the International Conference on Wildlife Ecology and Transportation. Florida Department of Transportation, Tallahassee, Florida, USA. 1 CD-ROM.

SEILER, A. 2001. Ecological Effects of Roads A review. Swedish University. Introductory Research Essay. Uppsala, Swedish. 40p.

SEILER, S.; HELLDIN, J-O. \& SEILER, C. 2004. Road mortality in Swedish mammals: results of a drivers' questionnaire. Wildlife Biology, 10: 225-233.

SESHADRI, K.S. \& GANESH, T. 2011. Faunal mortality on roads due to religious tourism across time and spacein protected areas: A case study from south India. Forest Ecology and Management, 262: 1713-1721, http://dx.doi.org/10.1016/j.foreco.2011.07.017

SHEPARD, D.B.; KUHNS, A.R.; DRESLIK, M.J. \& PHILLIPS, C.A. 2008. Roads as barriers to animal movement in fragmented landscapes. Animal Conservation, 11: 288-296, http://dx.doi. org/10.1111/j.1469-1795.2008.00183.x

SHINE, R.; LEMASTER, M.; WALL, M.; LANGKILDE, T. \& MASON, R. 2004. Why did the snake cross the road? Effects of roads on movement and location of mates by garter snakes (Thamnophis sirtalis parietalis). Ecology and Society, 9: 9.

SILVERMAN, B.W. 1986. Density Estimation for Statistics and Data Analysis. Chapman \& Hall, London. 175p.

SMITH, D.J. 2003. Ecological Effects of Roads: Theory, Analysis, Management and Planning Considerations. PhD Thesis University of the State of Florida. Gainesville, USA.

SMITH, L.L. \& DODD, C.J. 2003. Wildlife mortality on highway US 441 across Payne's Prairie, Alachua County, Florida. Florida Naturalist, 66: 128-140.

SPELLERBERG, I.F. 2002. Ecological effects of roads. Science Publishers, Enfield, New Hampshire, USA. 251p.

SPSS 15.0. 2006. Command Syntax Reference, SPSS Inc., Chicago.

SULLIVAN, B. K. 1981. Observed differences in body temperature and associated behavior of four snake species. Journal of Herpetology, 15: 245-246, http://dx.doi.org/10.2307/1563390 SUNDAR, G.K.S. 2004. Mortality of herpetofauna, birds and mammals due to vehicular traffic in Etawah District, Utter Pradesh, India. Journal of the Bombay Natural History Societ, 101: 392-398
SZERLAG, S. \& MCROBERT, S.P. 2006. Road occurrence and mortality of the northern diamondback terrapin. Applied Herpetology, 3: 27-37, http://dx.doi. org/10.1163/157075406775247058

TREMBATH, D.F. \& FEARN, S. 2008. Body sizes, activity times, food habits and reproduction of brown tree snakes (Boiga irregularis) (Serpentes: Colubridae) from tropical north Queensland, Australia. Australian Journal of Zoology, 56: $173-$ 178, http://dx.doi.org/10.1071/ZO08008

TREWEEK, J.S.; THOMPSON, N.V. \& JAPP, C. 1993. Ecological assessment of road developments. A review of environmental statements. Journal of Environmental Planning and Management, 36: 295-308, http://dx.doi.org/10.1080/09640569308711948

TROCMÉ, M.; CAHILL, S.; DE VRIES, H.J.G.; FARRALL, H.; FOLKESON, L.; FRY, G.; HICKS, C. \& PEYMEN, J. (eds.). 2002. COST 341. Habitat Fragmentation due to transportation infrastructure: The European Review. Office for Official Publications of the European Communities, Luxembourg. 253p.

TROMBULAK, S.C. \& FRISSELL, C.A. 2002. Review of ecological effects of roads on terrestrial and aquatic communities. Conservation Biology. 14: 18-30, http://dx.doi.org/10.1046/ j.1523-1739.2000.99084.x

VAN GELDER, J.J. 1973. A quantitative approach to the mortality resulting from traffic in a population of Bufo bufo L. Oecologia, 13: 93-95

VIEIRA, E.M. 1996. Highway mortality of mammals in central Brazil. Journal of the Brazilian Association for the Advancement of Science, 48: 270-271.

VIJAYAKUMAR， S.P.; VASUDEVEN，K.; ISHWAR， N.M. 2001. Herpetofaunal mortality of Roads in the Anamalai Hills. Southern Western Ghats. Hamadryad, 26: 253-260.

WHITAKER, R. \& CAPTAIN, A. 2004. Snakes of India: The Field Guide. Draco Books, India. 494p.

WPA. 1972. Wildlife (Protection) Act1972. Ministry of Environment \& Forests. Government of India.

YAHNER, R. 1988. Changes in wildlife communities near edges. Conservation Biology, 4: 333-339, http://dx.doi. org/10.1111/j.1523-1739.1988.tb00197.x

Submetido em 30/08/2012. Aceito em 14/02/2013. 